\title{
Ein likeverdig skule i framtida?
}

\author{
Om dei som strevar i skulen ${ }^{1}$
}

\author{
Peder Haug \\ Høgskulen $i$ Volda, Norge
}

\begin{abstract}
Samandrag
Artikkelen handlar om tiltak for skulen i framtida i innstillingane frå Ludvigsenutvalet. Den norske regjeringa utnemnde dette utvalet i 2013 for å vurdere faga i grunnopplæringa opp mot krava til kompetanse i eit framtidig samfunns- og arbeidsliv. Innstillingane omtalar ikkje tilhøva for den store gruppa elevar som strevar i skulen særskilt, men nokre av forslaga vil kunne styrke skulen på område som kan verke positivt for dei. Første del av artikkelen gjeld kva konsekvensar forslaga kan få for elevar som strevar i skulen, og som står i fare for å verte marginaliserte. Det gjeld meir vekt på djupnelæring, auka fleksibilitet i fordelinga av fag og timar og ønske om eit breiare syn på kompetansen skulen har ansvaret for å utvikle. Korleis desse endringane vil kome til å fungere er avhengig av måten dei vert sette i verk på. Del to av artikkelen handlar difor om kva ein må ta omsyn til for at framlegga skal ha ein rimeleg sjanse for å fungere på ein god måte for dei elevane som her er omtala. Hovudpoenga er at det må ligge eit klart profesjonsfagleg perspektiv til grunn. Framlegga må forståast ut frå den kompleksiteten dei står i og representerer og endeleg må ansvaret for gjennomføringa vere institusjonelt, ikkje berre individuelt.
\end{abstract}

\section{Nøkkelord: Ludvigsenutvalget; marginalisering; inkludering; implementering}

\begin{abstract}
The article deals with The Ludvigsen committee's suggestions for future changes in school. The Norwegian Government appointed this committee in 2013 to assess primary and secondary education subjects in terms of the competence society and working life will need in the future. The committee's recommendations do not specifically refer to the group of students in need of special support and being in danger of marginalization in school. However, some of the proposals could improve school's function for them. The first part of the article is about what consequences some of the recommendations could have for these students in school. The elements discussed are emphasize on depth learning, increased flexibility in distribution of subjects and teaching hours and a broad perspective on what student competences school should be responsible for. How these changes will function for the students depends upon the implementation. Part two of the article therefore deals with what to consider making the recommendations a chance to succeed. The main points are to build on professional ground, to understand the complexity of the challenges and to make institutions responsible, not only individuals.
\end{abstract}

\section{Keywords: The Ludvigsen committee; marginalization; inclusion; implementation}

Received: January 2016; Accepted: August 2016; Published: December 2016

\footnotetext{
^Korrespondanse: Peder Haug, Høgskulen i Volda, Norge, E-post: Peder.Haug@Hivolda.no

${ }^{1}$ Takk til anonyme fagfeller for særs konstruktive forslag om endringar i teksten. 
Den kompetansen skulen gir, legg mykje av grunnlaget for elevane si vidare karriere i livet. Å klare seg på skulen i Noreg aukar sjansane for at det vil gå bra også seinare, både privat og i samfunnslivet (Hattie, 2013). Skulen legg eit grunnlag for livskvaliteten for kvar enkelt ved måten kvalifiserings- og danningsoppdraget er gjennomført på. Skulen skal tuftast på grunnleggande verdiar som sosial rettferd, likestilling og likeverd. I det ligg at alle elevar i skulen skal ha eit positivt læringsmiljø som gir dei fagleg og personleg utbyte, uavhengig av bakgrunn og føresetnader. Trass i intensjonane maktar ikkje skulen å oppfylle forventingane om å gje gode vilkår for alle. Mange elevar strevar på skulen. Dei står i fare for marginalisering, og for å falle utanfor samfunns- og arbeidsliv (Frønes \& Strømme, 2014).

Ludvigsenutvalet $^{2}$ har levert to innstillingar om skulen i framtida (Kunnskapsdepartementet, 2014, 2015a). I samsvar med mandatet handlar dei om framtidskompetansar og faginnhaldet i skulen. Dei tek i liten grad opp spørsmål om elevane som strevar. Mandatet nemner dei heller ikkje. Forslaga frå utvalet kan likevel ha konsekvensar for denne gruppa. Det er grunnlaget for at artikkelen drøfter vilkåra for elevane som strevar i skulen, ut frå framlegga frå Ludvigsenutvalet. Drøftingsspørsmåla er desse: Korleis er tilhøva for elevar som strevar i grunnskulen, og kva er utsiktene for dei ut frå sentrale forslag i innstillingane frå Ludvigsenutvalet?

Artikkelen legg til grunn forsking frå norsk skule. Det er gjort ein gjennomgang av innstillingane frå Ludvigsenutvalet for å finne dei mest sentrale forslaga om innhaldet i skulen i framtida med særleg tanke på elevane som strevar. Diskusjonen om kva utfordringar ein står over for om og når desse forslaga skal realiserast er basert på nasjonal og internasjonal reformforsking.

\section{Elevar som strevar}

Elevar som strevar er ei samansett og vanskeleg definerbar gruppe. Det er elevar som av ulike grunnar ikkje meistrar dei faglege og sosiale utfordringane i skulen. Dette gjeld minst $25 \%$ av alle elevane i skulen, truleg fleire. Til dømes skårar rundt ein firdel av elevane under kritisk grense på PISA-undersøkingane i matematikk og lesing (Kjærnsli \& Olsen, 2013). Talet på elevar som ikkje fullfører vidaregåande skule innanfor normert tid er på rundt 30 \% (Statistisk sentralbyrå, 2015). Ein del elevar har psykiske vanskar, andre er råka av låg motivasjon eller problemåtferd. Alle desse vil vere $\mathrm{i}$ risikogruppa for manglande kvalifisering for vaksenlivet (Breilid \& Sørensen, 2014). Talet på elevar dette gjeld er høgt, det er mellom eitt- og to hundre tusen individ. Dei møter ein skule som har sett ein standard for kva som skal til for å lukkast der. Denne standarden maktar dei ikkje å følgje, desse elevane passar ikkje inn. Måten skulen har organisert og utforma innhald og arbeidsmåtar på skaper desse utfordringane: "Given a finite repertoire of standard programs, students whose needs fall outside the standard programs must be forced into them or out of the classroom, ...» (Skrtic, 1992, s. 228). Dei som blir pressa ut i grunnskulen får oftast spesialundervisning. Dei andre blir

\footnotetext{
${ }^{2}$ Ludvigsenutvalet vart oppnemnt av den norske regjeringa i 2013 for å vurdere innhaldet i grunnopplæringa opp mot krava til kompetanse i eit framtidig samfunns- og arbeidsliv.
} 
verande, mange av dei blir underytarar. Allereie på 1950-talet viste norsk forsking at mange elevar med gode læreføresetnader presterte lågt fordi dei hadde vanskar med å tilpasse seg livet i skulen (Dale, 2008).

At elevar har vanskar med å fungere i skulen, seier lite om kva kapasitet dei har for å lære. Også svært gåverike elevar kan vere i denne risikogruppa (Lie, 2014). Utbytet av skulen heng nært saman med den innsatsen skulen set inn for den enkelte eleven: «... given the level of resources we are able or willing to commit to the education of all students, and the way in which these resources are used in practice, a certain proportion of students will not succeed» (Slavin, Karweit \& Madden, 1989, s. 3). Eller som det går fram av ein OECD-rapport: Det er mogleg å gje alle elevar eit godt utbyte i skulen, berre tilbodet er lagt nok til rette (OECD, 1999).

\section{Utdanningspolitiske ideal}

Ei av dei største utfordringane i skulen er å meistre mangfaldet mellom elevane, å undervise slik at elevar med ulike føresetnader får eit godt utbyte. Skulehistoria kan lesast som ei skildring av korleis ein gradvis har teke meir og meir omsyn til å møte elevvariasjonen på ein positiv måte, og etter kvart skapt ein inkluderande skule for alle. Den same historia viser også at det har vore motstand mot å opne skulen. Debattane om dette kan forståast som eit uttrykk for korleis ulike elevgrupper har vore verdsette, og dermed om skulen si rolle i samfunnet.

Den organisatorisk differensierte grunnskulen hadde vi fram til 1970-talet. Han sorterte elevane ut frå deira funksjon og interesser. Til grunn låg eit ønske om å gjere skulen til ein normalskule, for dei såkalla normale elevane (Simonsen, 2012). Dei som kunne ligge samfunnet til byrde skilde ein ut. Nokre av dei gjekk i spesialskular, andre fekk undervisninga på eit meir elementært nivå enn resten (linjer og kursplanar) og nokre forlét skulen tidleg.

Tankar om normalisering av levekåra for menneske med funksjonshemming kom på 1960-talet, og fekk konsekvensar for alle som hadde streva i skulen. Alle skulle sikrast høg livskvalitet gjennom å vere i den same fellesskapen (Stangvik, 1987). I det ligg ei erkjenning av utdanning både som ei sosial og ei fagleg utfordring som skal løysast gjennom samhandling mellom alle elevar i opplæringa i skulen. Det representerer det vide mandatet for skulen.

I prosessen fram til ein skule for alle var lova om grunnskulen frå 1975 sentral. Den tok opp i seg lova om spesialskulane (frå 1951) og lova om folkeskulen (frå 1969) og gav alle elevar rett til opplæring. Omgrepet «ikkje opplæringsdyktig» innført ein gong på 1800-talet gjaldt ikkje lenger. Integrering i ordinær skule og i felles klasse skulle vere det vanlege for alle elevar. All organisatorisk differensiering på ungdomstrinnet vart teken bort. Spesialskulane vart lagde ned, spesialundervisninga skulle gå føre seg i den vanlege skulen. Idealet vart undervisning i samla og vanleg klasse gjennom heile skuleløpet, for alle elevar.

Reform 97 skifta ut integreringsomgrepet med omgrepet inkludering, ein konsekvens av tilslutninga til Salamanca-erklæringa frå 1994 (UNESCO, 1994). Det var misnøye med praktiseringa av integrering i mange land. Den gagna 
ikkje elevane som streva. Dei vart plasserte i vanleg skule og klasse, men dei fekk ikkje gode nok vilkår for læring (Vislie, 2003). Inkluderinga skulle endre på det, den omfatta alle elevar som står i fare for ekskludering eller marginalisering i skulen. Idealet er ei vidareføring og ei klargjering av politikken om at alle elevar skal vere $i$ ein skule som gir dei vilkår for å vere med i fellesskapen, vere ekte deltakarar $\mathrm{i}$ verksemda i skulen, medverke og ikkje minst å få utbyte sosialt og fagleg ut frå eigne føresetnader (Haug, 2014).

Meldinga til Stortinget frå 2013 om grunnopplæringa «På rett vei. Kvalitet og mangfold i fellesskolen» går inn på fleire utfordringar med relevans for den elevgruppa som her er tema (Det kongelige kunnskapsdepartement, 2013). Mange av dei var framme også i meldinga «Kultur for læring» som la grunnlaget for Kunnskapsløftet (Det kongelige utdannings- og kunnskapsdepartement, 2004) og i tidlegare meldingar. Dei viser at det har vore og er eit mål å unngå marginaliseringseffekten som skulen har på ei rekkje elevar. Det skal mellom anna gjerast ved å redusere konsekvensane av sosial bakgrunn for elevane sine prestasjonar i skulen, å redusere omfanget av elevar som presterer under kritisk grense på sentrale område som lesing og rekning, å redusere skilnaden mellom kjønna i prestasjonar og trivsel i skulen, å få slutt på mobbinga i skulen, å redusere omfanget av spesialundervisning i skulen, å gi meir spesialundervisning innanfor ramma av den ordinære opplæringa, satse meir på tidleg innsats og å gje elevar med fleirkulturell bakgrunn dei same vilkåra i skulen som elevar med norsk bakgrunn.

\section{Tilstanden i skulen for elevar i risikogruppa}

Trass i mål, intensjonar og tiltak, skulen har ikkje fått til fundamentalt å endre dei funksjonane han har for dei elevane som strevar, sjølv om det er brukt mykje tid og ressursar, mellom anna på dei områda som er omtala ovanfor.

Djupedalutvalet slår fast at skulen rettsstridig ikkje oppfyller krava til eit godt læringsmiljø for alle elevane (Kunnskapsdepartementet, 2015b). Sosial bakgrunn spelar ei stor rolle for elevane sine læringsresultat (Bakken \& Elstad, 2012). Omfanget av tilkortkomarar i skulen er relativt stabilt, det gjeld både dei som presterer under kritisk grense i fag (Kjærnsli \& Olsen, 2013) og dei som ikkje fullfører vidaregåande innan normal tid (Statistisk sentralbyrå, 2015). Skilnaden mellom kjønna i skuleprestasjonar er no endå meir til fordel for jentene (Bakken \& Elstad, 2012), og framleis får dobbelt så mange gutar som jenter spesialundervisning (Utdanningsdirektoratet, 2014). Omfanget av mobbing er om lag som før (Wendelborg, 2016). Talet på elevar som får spesialundervisning er høgt, men har ein svak nedgang (Utdanningsdirektoratet, 2014). Det er fleire som strevar og som ikkje får spesialundervisning, som dei som får spesialundervisning. Dei fleste som strevar har låg trivsel og svak motivasjon for arbeidet i skulen. Det er lite tidleg innsats (Nordahl \& Hausstätter, 2009; Nordahl \& Sunnevåg, 2008). Elevar med fleirkulturell bakgrunn er framleis mellom dei som har størst vanskar med å klare seg godt i skulen, men med skilnader avhengig av kva land dei eller foreldra deira kjem frå (Utdanningsdirektoratet, 2012). 
Følgja er at skulen ikkje fungerer godt for ein del elevar. Skulen kan difor vere ein vond stad å vere for mange, med underyting, nederlag, vantrivnad, stigmatisering og utstøyting som resultat (Markussen, Frøseth \& Sandberg, 2011). Det vil seie fare for marginalisering. Det resultat strir mot ideane bak inkludering. Det er også politisk erkjent: «Etter departementets vurdering er det dermed behov for å forsterke tiltakene for å bedre læringsmiljøet til elevene, og i større grad enn tidligere forankre slike tiltak i den ordinære virksomheten til skolene» (Det kongelige kunnskapsdepartement, 2013, s. 56).

Dei uønskte tilstandane for elevane som strevar i skulen er langt frå nye. Det er svært alvorleg at skulen alltid har vore urettferdig. Han har fått halde fram med å vere det, ved at han har vore enklare for nokre elevar å vere i, tilpasse seg og få utbyte av, enn for andre. Saka er no at medvitet om det har vorte større. Det kjem dels av at vi har meir kunnskap om korleis skulen fungerer enn før, men også fordi dei negative konsekvensane av å kome til kort i skulen har vorte langt meir alvorlege. Det er så få andre alternativ til kvalifisering (Dale, 2008). For dei elevane som då ikkje maktar å få tilstrekkeleg utbyte av skulen, vil den utviklinga gje dei endå større utfordringar enn før. Og dei negative følgjene av å streve vil auke.

\section{Ludvigsenutvalet}

Ludvigsenutvalet drøfta innhaldet i skulen ut frå kva krav dei såg til kompetansar $i$ eit framtidig samfunns- og arbeidsliv. Alle framlegga om innhald gjeld den ordinære opplæringa. Utvalet har dessutan få elevperspektiv på innhaldet i framtidsskulen. Samfunnsbehovet er det sentrale i mandatet og er det primære i innstillinga. Eventuelle motsetningar mellom det som tener samfunnet og det som tener individa er ikkje trekte fram. Spørsmål om elevføresetnader, elevinteresser og kva innhald som skaper engasjement hos dei er meir perifere. Utvalet har heller ingen tilrådingar om spesielle tiltak for dei elevane som strevar. Innstillinga gjer såleis utfordringane knytte til sambandet mellom innhald og elevmangfald i skulen usynleg. Det som eventuelt skal løyse dei er læraren i klasserommet.

Framlegga frå utvalet kan sjølvsagt få konsekvensar for alle elevar. Det heng saman med at kvaliteten på den ordinære opplæringa bestemmer kor mange av dei som vil streve, det ligg i tenkinga om komplementariteten i skulen: Høg kvalitet på den ordinære opplæringa gjer til dømes at behovet for spesialundervisning blir mindre (Nordahl, Mausethagen \& Kostøl, 2009). Her presenterer eg det eg vurderer som dei tre mest sentrale framlegga til utvalet og relaterer dei til dei elevane som strevar.

\section{Djupnelæring}

Faga i skulen har over tid blitt meir og meir omfattande både i omfang, timetal (for nokre fag) og i krav til måloppnåing. Det får særlege negative følgjer for dei elevane som strevar. I Reform 97 var både mengda faginnhald og krava sett som eit stort problem, det var uråd å kome gjennom alt på ein god måte for dei fleste elevane 
(Haug, 2003). Ut frå Ludvigsenutvalet sine analysar har ikkje Kunnskapsløftet endra vesentleg på det. Resultatet har vorte mykje overflatelæring. Utvalet vil ha meir djupnelæring. «Å sette læreplanene ut i livet forutsetter ofte at bredde må vektlegges i opplæringen, og utvalget ser at det kan være utfordrende samtidig å skulle legge til rette for at elevene får arbeide grundig med det de skal lære i dybden» (Kunnskapsdepartementet, 2014, s. 94).

Djupnelæring er å lære noko grundig og med god forståing. Det krev tid, og då må mengda fagstoff blir mindre, men meir prioritert. Konsekvensen av djupnelæring er at det encyklopediske innhaldsidealet som lenge har dominert i norsk skule står for fall. Det idealet går ut på at elevane skal lære «litt» om «alt». Då blir det mykje stoff på kort tid. Det kan verte overveldande for nokre. Resultatet blir lite læring og overflatelæring. Alternativet, som utvalet omtalar som djupnelæring representerer eit eksemplarisk innhaldsomgrep: «... [at] den lærende ud fra et begrænset antal udvalgte eksempler arbejder sig frem til [...] almengyldige kundskaper, evner og holdninger» (Klafki, 2001, s. 166). Då kan nokre arbeide med det elementære til dei meistrar det, medan andre kan gå i djupna. Det betrar også vilkåra for å variere arbeidsmåtane.

\section{Fleksibilitet i fag- og timefordeling}

Det har nesten ikkje vore grenser for forslag om nytt innhald i skulen, innhald som tidlegare var ansvaret til familiane, arbeidslivet, det offentlege eller kyrkja. Lite av dette har kome inn, men presset er der alltid. Ludvigsenutvalet sitt forslag er å prioritere faginnhaldet endå kraftigare enn det har vore giort til no. Det er viktig at elevane lærer det som er sentralt $\mathrm{i}$ eit fagområde. Dei vil difor forenkle fagportefølgjen, ved å sjå fleire ulike fagområde i samanheng og ved å auke fleksibiliteten $\mathrm{i}$ fag og timefordeling. Det kan forenkle læringsarbeidet på tvers av fag, og det kan skape synergiar som gir meir tid til læring og til læring på tvers av fag. I kombinasjon med djupnelæringa vil forslaget om fagleg fleksibilitet også gjere det enklare for mange av elevane som strevar i skulen. Handlingsrommet blir større både fagleg og metodisk. Det gir utvida vilkår for betre fagleg progresjon, fagkonsentrasjon, og for å sjå samanhengar mellom fagområde og for å variere undervisninga. Auka fleksibilitet kan misbrukast, om det ikkje blir laga gode rutinar for korleis fleksibiliteten skal settast i verk. I dag skal alle avvik frå læreplanen gjerast som enkeltvedtak, regulert av forvaltningslova. Det gir føresette rett både til innsyn og til å godta eventuelle tilpassingar.

\section{Brei kompetanse, læringsmiljø og sosio-emosjonell utvikling}

Røvik og Pettersen (2014) nyttar omgrepet masteridear om idéstraumar som får stor legitimitet og utbreiing, og som kan utløyse og påverke reformer. Frå 1960-talet var det spenningar mellom to slike masteridear i skulen, ei innovativ og ei restaurativ utdanningspolitisk interesse (Telhaug, 1990). Den første stod for ein skule oppteken av gode prosessar og inspirerande miljø. Den andre prioriterte ein skule oppteken av fagleg kvalitet og kritiserte det faglege nivå på elevprestasjonane i skulen. Dei første linjene i innstillinga frå Hernesutvalet frå 1988 gjorde det klart at hovudutfordringa i 
utdanningspolitikken var at vi ikkje fekk nok kompetanse ut av «befolkningens talent» (Kultur- og vitenskapsdepartementet, 1988, s. 7).

Dokumentasjonen kom for alvor med PISA-«sjokket» i 2001. Der presterte norske femtenåringar gjennomsnittleg $\mathrm{i}$ lesing, naturfag og matematikk samanlikna med dei andre OECD-landa (Lie, Kjærnsli, Roe \& Turmo, 2001). Den politiske tolkinga vart raskt til at prestasjonane var middelmådige (Bergesen, 2006) og med omlegging av skulepolitikken som følgje. Fagleg læring skulle no vere det sentrale for skulen, slik statsråd Kristin Clemet formulerte seg i planane for den neste reforma, Kunnskapsløftet (Det kongelige utdannings- og kunnskapsdepartement, 2004). Perspektivet var her at ein burde nå betre læringsresultat utan at det skulle gå ut over trivsel og sosial utvikling. Det skjerpa omsynet til den faglege læringa, og særleg i dei sentrale teorifaga, og fungerte som eit auka læringstrykk både på lærarar og elevar. Det skapte eit grunnlag for at fleire tok til å streve, mellom anna auka omfanget av spesialundervisning (Mathiesen \& Vedøy, 2012).

Ludvigsenutvalet foreslår særleg to tiltak som sameinar dei to masterideane, og som kan tene den elevgruppa som er den sentrale her. Det eine er å vere opptekne av eit breitt kompetanseomgrep. Det inneheld vektlegging av alle fagområda i læreplanen framfor den noko einsidige vekta på nokre teorifag som har prega utdanningspolitikken dei seinare åra. Dei nemner spesielt behovet for å satse meir på praktiske og estetiske fag. Kompetanseomgrepet inkluderer også område som å kunne lære, kommunisere og utforske. Det andre elementet er den sterke vekta utvalet legg på at skulane skal arbeide med læringsmiljøet, der dei også legg vekt på den sosiale og emosjonelle utviklinga hos elevane. Her ligg utvalet nært opp til ideane om den inkluderande skulen: «At elevene lærer verdien av å bety noe for andre, stå opp for andre og ta ansvar for andre, er [...] av stor betydning [...].» (Kunnskapsdepartementet, 2015a, s. 13). Eit breitt kompetanseomgrep, vekt på læringsmiljø og sosio-emosjonell utvikling som sentrale element $i$ arbeidet $i$ skulen vil vere til stor hjelp for mange av dei elevane som strevar. Smal kompetanse, svakt læringsmiljø og einsidig vekt på det faglege skaper vilkår for læring og utvikling som ikkje alle elevar meistrar like godt.

\section{Vil framlegga i Ludvigsenutvalet gjere forskjell?}

Det er eit skilje mellom inkrementelle (eller trinnvise) og fundamentale endringar (Cuban, 1993). Inkrementelle endringar er primært avgrensa instrumentelle og tekniske fornyingar av korleis skulen organiserer og gjennomfører arbeidet innanfor eksisterande ordningar. Fundamentale endringar påverkar dei grunnleggande strukturane som gjeld skulen sin funksjon. « ... basic structures are flawed at their core and need a complete overhaul, not renovations» (Cuban, 1993, s. 3).

Dei endringane som her er omtala frå Ludvigsenutvalet vil sjølvsagt ikkje løyse alle utfordringane som er knytt til elevar som strevar. Dei rører ved viktige område i den ordinære opplæringa, dei bryt med eksisterande ordningar og kan endre skulen fundamentalt. Det tyder å skape heilt andre føresetnader for læring for alle, og spesielt for dei som strevar. Difor er framlegga interessante. Til det må knytast 
atterhald om dei i det heile blir gjennomførde for å få fram det fundamentale potensialet som ligg i dei.

At ei kvar endring skal vere til det betre for alle er ei reformoptimistisk grunngjeving (Røvik, 2014a). Reformer i skulen er alltid sette i gang med lovnader om gode resultat på område som er viktige for enkeltindivid og samfunn (David \& Cuban, 2010). I dette tilfellet er ein heilt avhengig av at endringane når inn i aktiviteten i klasseromma. Det som elles måtte gå føre seg i saka er mindre interessant. "Yet, reform policies too often go awry as they wend their ways into schools and classrooms. The gap between policy and practice remains vast» (David \& Cuban, 2010, s. 181). Politikarar vedtek reformene. Lærarar har ansvaret for å gjere dei om til praksis. Avstanden mellom formuleringsarenaene og realiseringsaktørane er stor, og det påverkar resultatet (Lindensjö \& Lundgren, 2000).

Mange elevar strevar i skulen. Slik har det vore lenge, og det er gjort mange forsøk på å endre på det, men utan å lukkast. Mange lovnadar i utdanningspolitikken blir ikkje oppfylte (Fullan, 2001; Røvik, 2014a; Sarason, 1990). Både nasjonal og internasjonal forsking formidlar det i kraftfulle vendingar, og med ein omfattande og overtydande dokumentasjon, berre boktitlane åleine er tydelege på det: «The predictable failure of educational reform» (Sarason, 1990), «So much reform, so little change» (Payne, 2010), «Oversold and underused» (Cuban, 2001), «Reforming again, again and again» (Cuban, 1990). I Noreg kjem liknande resultat fram i evalueringane både av Reform 97 og av Kunnskapsløftet (Haug, 2003; Karseth, Møller \& Aasen, 2013). Det kan tolkast som eit uttrykk for at skulen som system er ganske rigid og lite endringsorientert.

Det står i motsetning til ei erfaring om at skulen er i kontinuerleg omvandling. Verda, nasjonen og lokalmiljøa er heile tida i endring, og det påverkar skulen. Difor er ikkje alle endringane som skjer slike som det er gjort vedtak om. Alle organisasjonar, også skulen er prega av irrasjonalitet, at aktiviteten ikkje nødvendigvis samsvarar med den som det var intensjonar om (Brunsson, 2000).

Kva er det ein må ta omsyn til for å unngå endå ei reform som ikkje når måla sine? Utvalet er innom spørsmålet, men implementeringa er omtala svært generelt. At det er så lite merksemd om korleis oppnå det ein er ute etter er eit tema både for 22. julikommisjonen (Statsministerens kontor, 2012) og OECD (OECD, 2011). Begge peika på at vi i Noreg er gode til å formulere høge intensjonar og ambisjonar, men vi er ikkje like dyktige til å gjennomføre dei i praksis. Spørsmålet vidare her er kva ein bør ta omsyn til for at framlegga til Ludvigsenutvalet skal fungere positivt for elevane som strevar, om dei vert vedtekne. Grunnlaget for å svare er henta frå nasjonal og internasjonal reformteori og reformforsking.

\section{Strukturelle og profesjonelle endringar}

Skiljet mellom strukturelle og profesjonelle endringar kan vere ei forklaring på den motseiinga som ofte kjem fram om endringane i skulen, her formidla frå ei melding til Stortinget:

Det er forholdsvis lett å få lærere til å undervise i nytt stoff, å utvikle nye lærebøker eller gi skolen nye funksjoner som f.eks. spesialundervisning og yrkesorientering. 
Det er vanskelig å utvikle en kvalitativt bedre undervisning, antakelig fordi dette krever en ny forståelse av skolen og dets plass i samfunnet. (Kirke- og undervisningsdepartementet, 1984, s. 4)

Sitatet handlar om eit skilje mellom strukturelle og profesjonelle endringar. Ved dei fleste reformene i skulen har det strukturelle vore på plass i tide, anten det gjeld nye fag, nye læreplanar, fleire skuleår, nye lærebøker eller endra eksamensordning. Utfordringa har vore å gje opplæringa den ønskte forma, retninga og innhaldet. Det vil seie at lærarane har forstått og er i stand til å gjennomføre den profesjonelle utfordringa. Det er ei langt vanskelegare oppgåve å løyse enn den strukturelle, og den tek som regel lang tid.

Djupnelæring, innhaldsfleksibilitet og ei brei tilnærming til innhald og arbeidsformer har klare strukturelle sider. Mange av dei er knytte til læreplanen og korleis den nye læreplanen blir forma ut. Skal den få fundamentale konsekvensar for elevane og særleg for dei som strevar, vil den nye læreplanen også utfordre lærarkompetansen, altså ei profesjonell utfordring. Ei kvar reform i skulen er avhengig av at arbeidet i klasserommet fungerer slik det er tenkt. Reformer som inneheld tiltak rundt elevane og elevane si læring har størst verknad, seier OECD (2015). Det er då ein peikar på kor viktig lærarane er for å få endringa til å fungere.

Konsekvensen av desse framlegga er at det må skapast nye roller for lærarane og dermed også for elevane. Dei må gå fram på andre måtar enn før i arbeidet i skulen, og legge andre syn på læring til grunn enn dei som har vore rådande. Det er eit omfattande og langvarig utviklingsarbeid.

\section{Høge ambisjonar - krevjande utfordringar}

Skulen som organisasjon er eigentleg ikkje spesielt komplisert. Det ligg nært å tru at sidan organisasjonen er oversiktleg og relativt enkel, gjeld det også verksemda der. Slik er det ikkje. Forklaringa på at ein ikkje når dei måla som er sette for alle elevar, kan difor vere at ein har tatt for lett på det.

Å gje opplæring som alle elevar har utbyte av er utfordrande. Og grunnen er det pedagogiske paradokset (von Oettingen, 2001): Å vere lærar er å endre og forme andre individ, på mange livsområde. Men læraren kan ikkje direkte forme eller danne eleven som sjølvstendig og autonomt individ, det må eleven sjølv gjere gjennom sin eigen innsats. For læraren handlar opplæringa difor ikkje berre om å formidle og overføre objektiv og nøytral kunnskap, men om å legge grunnlaget for at elevane tek opp i seg og personleggjer verdiar, haldningar og kjensler og utviklar sjølvoppfatning og tilhøvet til alle andre både sosialt og kulturelt.

Lærarane skal hjelpe til slik at eit kvart barn skal verte eit sjølvstendig fungerande individ på alle utviklingsområda. Det er ei stor utfordring, og med usikkert utfall. Biesta (2014) drøfter denne risikoen i opplæringa. Lærarane må arbeide med levande individ og ikkje med maskinar. Risikoen kjem av at undervisninga handlar om møte mellom menneske, og dermed om relasjonar. Og dei kan ikkje bestemmast på førehand eller konstruerast på kunstig vis. Dei må skapast i møtet mellom individa. 
Ei kvar reform i skulen skal hjelpe lærarane til å gjere denne risikofylte og paradoksale oppgåva betre. Dilemmaet er at for å få vedtak om reformer må bodskapen gjerast overtydande. Han må tilfredsstille mange ulike interessegrupper. Det kan vere nødvendig for å få tilslutning og vedtak. Faren er då at ein ikkje tek omsyn til at utdanning er kompleks og innfløkt (David \& Cuban 2010). Når politikken lovar for mykje i høve til innsatsane blir resultatet negativt. Reformer er då overselde (oversold) (Cuban, 2001). Ei anna forklaring på det same er at skulepolitikk tek utgangspunkt i ideologi meir enn i erfaring. «There is no doubt that ideological rigidity is among the main reasons it takes us so long to learn so little» (Payne, 2010, s. 9).

Det har vore knytt store ambisjonar og forventingar til at skulen skulle makte å møte utfordringane for alle elevar på ein konstruktiv og god måte. Skal Ludvigsenutvalet sine forslag gje slike resultat, er det avgjerande at det komplekse i dei blir erkjent og ikkje undervurdert. Då må ein syte for relevant lærarkompetanse som sameiner omsyna både til fagleg og pedagogisk aktivitet. Då trengst det ei grundigare avklaring av kva slags kompetansar desse profesjonsutøvarane treng for også å kunne møte behova hos dei elevane som strevar. Sannsynlegvis må ein både utvikle kompetansar som er tilpassa årsaka til at nokre elevar strevar (Brownell, Sindelar, Kiely \& Danielson, 2010), og utvikle og forbetre dei allmenne strategiane for undervisning (Mitchell, 2008).

\section{Endring skaper motstand}

Når reformer ikkje blir sette i verk i samsvar med intensjonane kan det vere ein konsekvens av svak translasjon av reformer, omsettinga frå idé til praksis (Røvik, 2014b). Kravet om endring blir ofte møtt med både latent og aktiv motstand. Han kjem mange stader i frå. Skulen har ein godt utvikla tendens til å halde fram i etablerte måtar å arbeide og fungere på. Omgrepet «frosne ideologiar» har vore nytta om fenomenet, at tidlegare reguleringar, haldningar og løysingar eksisterer i det skjulte i institusjonane sjølv lenge etter at dei formelt var avskaffa (Liedman, 1997). Dei er der som strukturar, kunnskapar, haldningar, rutinar og kompetansar og held det som går føre seg i dei gamle spora. Det kan forståast som ei form for latent institusjonell motstand, som kjem i tillegg til den individuelle motstanden ein alltid finn i samband med reformer i skulen. Svak støtte og lavt engasjement kan også vere årsak til manglande gjennomføring. Fråveret av uvisse og konfliktar knytte til ambisjonar og aktivitet er ein viktig føresetnad for god gjennomføring (Brunsson, 2000). I det ligg også krav om konsistens i politikken, semje mellom aktørane og vilje til samla innsats over lang tid. Som det blir sagt i ein analyse av arbeidet med inkludering $\mathrm{i}$ dei fleste europeiske landa: "If inclusion, for all its complexity, is such an important principle, why is it not a readily identifiable, stand-alone entity in policy? And why is inclusion so often only mentioned in passing in many policies?» (Hardy \& Woodcock, 2015, s. 117).

Ordninga både med integrering og seinare inkludering er langt frå følgt opp med semje. Det har vore til dels stor motstand både politisk og pedagogisk (Haug, 1999), og både definisjonen av omgrepa og operasjonaliseringa av dei har variert (Haug, 2014). Praktiseringa av regelverket mange stader er ikkje i samsvar med 
føresetnadane, og at det gir svært ulike vilkår for læring (Kunnskapsdepartementet, 2009).

Å legge alt ansvar for kvaliteten i opplæringa på lærarane ved å uttrykke kor mykje dei har å seie, er eit smart taktisk grep. Realiteten er at lærarane ikkje maktar alt. Kvaliteten på undervisninga heng nært saman med kunnskaps- og kompetansenivået hos kvar enkelt lærar, men også med kvaliteten på det kollektive fagmiljøet ved institusjonen. Gode lærarar bli betre av å arbeide i gode skular, og dei får dårlegare resultat om dei arbeider ved skular som ikkje er så gode. Dei beste skulane er kollektivt orienterte, dei tilsette er gode til å samarbeide og dei er kunnskapsbaserte i samarbeidet dei driv med (Fullan \& Quinn, 2016).

Motstand mot endring kan møtast med kollektiv motkraft. Det krev tydeleg og viljesterk leiing på alle nivå. Særleg treng dei profesjonelle endringane eit tett og godt leiarskap, fordi dei er mest problematiske å få til, og få til å vare. Skule-eigarane og skuleleiarane er viktige partar i å gjere skulen god, og til å oppnå endring (Fullan \& Quinn, 2016). Og gode skule-eigarar får gode skuleleiarar. I Essunga kommune i Sverige har dei kome eit godt stykke på den vegen. Der utvikla dei skulane frå å vere mellom dei aller lågast presterande i landet til å verte mellom dei aller beste på nokre få år. Det skjedde ved hjelp av eit gigantisk utviklingsarbeid som involverte alle dei sentrale skuleaktørane i kommunen: elevar, foreldre, lærarar, skuleleiarar, kommunale leiarar og politikarar. Svært mykje av utviklingsarbeidet har handla om å skape og støtte nye lærar- og elevroller, og til å nytte ressursane i skulen på mest mogleg fleksibel måte. Alle elevane tente på endringa, men mest dei som streva (Persson \& Persson, 2012).

\section{Til slutt}

Innstillingane om skulen $\mathrm{i}$ framtida tek ikkje tak $\mathrm{i}$ at mange elevar strevar i skulen, og at det er store individuelle skilnader $\mathrm{i}$ korleis dei meistrar dei faglege utfordringane. I forslaga til Ludvigsenutvalet ligg likevel ein kime til å styrke skulen som ein stad å lære for alle elevar, også dei som strevar. Djupnelæring, fleksibilitet og brei kompetanse kan skape betre vilkår for alle elevar, og gjere skulen meir likeverdig. Utfordringa er å vere $\mathrm{i}$ stand til å vedta og sette ut i livet ein politikk der desse elementa verkeleg er tilstade på ein god måte. Det er først når vi ser praksisen at politikken kan vurderast.

Det er peika på at skal skulen endrast fundamentalt for dei elevane som strevar krev det merksemd om dei profesjonelle utfordringane der det å endre lærar- og elevrollene er sentralt. Det er komplekse og krevjande oppgåver, og dei kan berre møtast gjennom omfattande utviklingsarbeid. Endring fører også med seg eit behov for å bygge den kollektive kulturen ved skulane, og i det ligg også å skape føresetnader for godt leiarskap.

Å konstruere ein skule som også fungerer for elevar som tradisjonelt strevar er ei omfattande og stor oppgåve. Det er den av mange grunnar. Kunnskapen om korleis det bør gjerast er slett ikkje eintydig, det trengst meir erfaring og meir kunnskap. Viljen og evna til å gjere dei endringane som er nødvendige er sannsynlegvis heller 
ikkje på plass. I ein skule for alle, må alle ta omsyn til kvarandre. Det er ikkje like enkelt. Og til sist, å skape denne skulen vil ta lang tid, fordi den mest grunnleggande utfordringa er at det er menneska som må endrast og som må endre seg.

\section{Biografi}

Peder Haug (f. 1947) er professor i pedagogikk ved Institutt for pedagogikk, Høgskulen i Volda. Han er Cand. Paed frå Universitetet i Oslo og har doktorgrad i pedagogikk frå Stockholm Universitet. Han har arbeidd ved Høgskulen i Volda sidan 1976, men med lengre engasjement ved Senter for barneforsking NTNU, Norges forskningsråd, Universitetet i Stavanger, Uppsala Universitet, Vetenskapsrådet i Sverige og Skolverket i Sverige. Han har gitt ut ei rekkje bøker og artiklar med tema som gjeld barnehage, skule, lærarutdanning og spesialundervisning.

\section{Referanser}

Bakken, A. \& Elstad, J. I. (2012). For store forventninger?: kunnskapsløftet og ulikhetene $i$ grunnskolekarakterer. Oslo: Norsk institutt for forskning om oppvekst, velferd og aldring. NOVA-rapport nr. 7.

Bergesen, H. O. (2006). Kampen om kunnskapsskolen. Oslo: Universitetsforlaget.

Biesta, G. J. J. (2014). Utdanningens vidunderlige risiko. Bergen: Fagbokforlaget.

Breilid, N. \& Sørensen, P. M. (2014). Skole og læringsbetingelser for ungdom i risiko. I E. Befring \& R. Tangen (Red.), Spesialpedagogikk, 5. utg. (s. 627-644). Oslo: Gyldendal.

Brownell, M. T., Sindelar, P. T., Kiely, M. T. \& Danielson, L. C. (2010). Special Education Teacher Quality and Preparation: Exposing Foundations, Constructing a New Model. Exceptional Children, 76(3), $357-377$.

Brunsson, N. (2000). The Irrational Organization. Irrationality as a basis for organizational action and change. Bergen: Fagbokforlaget.

Cuban, L. (1990). Reforming Again, Again and Again. Educational Researcher, 19(1), 3-13.

Cuban, L. (1993). How Teachers Taught. Constancy and Change in American Classrooms 1880-1990. 2nd ed. New York: Teacher College Press.

Cuban, L. (2001). Oversold and Underused. Computers in the Classroom. Cambridge: Harvard University Press.

Dale, E. L. (2008). Fellesskolen - reproduksjon av sosial ulikhet. Oslo: Cappelen Akademisk Forlag.

David, J. L. \& Cuban, L. (2010). Cutting Through the Hype. The Essential Guide to School Reform. Cambridge: Harvard Education Press.

Det kongelige kunnskapsdepartement. (2013). På rett vei. Kvalitet og mangfold $i$ fellesskolen. Meld. St. 20 (2012-2013). Oslo: Kunnskapsdepartementet.

Det kongelige utdannings- og kunnskapsdepartement. (2004). Kultur for lering. St.meld. nr. 30 (2003-2004), Oslo: Utdannings- og kunnskapsdepartementet.

Frønes, I. \& Strømme, H. (2014). Risiko og marginalisering: norske barns levekår i kunnskapssamfunnet (2. utg.). Oslo: Gyldendal akademisk.

Fullan, M. \& Quinn, J. (2016). Coherence. The right drivers in action for schools, districts, and systems. London: Sage.

Fullan, M. G. (2001). The New Meaning of Educational Change, 3rd ed. New York: Teachers College Press.

Hardy, I. \& Woodcock, S. (2015). Inclusive education policies: discourses of difference, diversity and deficit. International fournal of Inclusive Education, 19(2), 141-164.

Hattie, J. (2013). Synlig lering - for lcerere. Oslo: Cappelen Damm Akademisk.

Haug, P. (1999). Spesialundervisning i grunnskolen. Grunnlag, utvikling og innhald. Oslo: Abstrakt.

Haug, P. (2003). Evaluering av Reform 97. Oslo: Noregs forskingsråd.

Haug, P. (2014). Dette vet vi om inkludering. Oslo: Gyldendal Akademisk.

Karseth, B., Møller, J. \& Aasen, P. (Red.). (2013). Reformtakter. Om fornyelse og stabilitet $i$ grunnopplcringen. Oslo: Universitetsforlaget.

Kirke- og undervisningsdepartementet. (1984). Om det pedagogiske utviklingsarbeidet i skolen og om forsøksvirksomheten i skoleverket skoleårene 1983-84 og 1982-83. St.meld. nr. 79 (1983-84). Oslo: Kirke- og undervisningsdepartementet.

Kjærnsli, M. \& Olsen, R. V. (2013). Fortsatt en vei å gå. Norske elevers kompetanse i matematikk, naturfag og lesing $i$ PISA 2012. Oslo: Universitetsforlaget. 


\section{Peder Haug}

Klafki, W. (2001). Dannelsesteori og didaktikk - nye studier. Århus: Klim.

Kultur- og vitenskapsdepartementet. (1988). Med viten og vilje. NOU 1988:28. Oslo: Forvaltningstjenesten.

Kunnskapsdepartementet. (2009). Rett til laring. NOU 2009:18. Oslo: Departementenes servicesenter. Informasjonsforvaltning.

Kunnskapsdepartementet. (2014). Elevenes laring $i$ fremtidens skole. Et kunnskapsgrunnlag. NOU 2014:7. Oslo: Departementenes sikkerhets- og serviceorganisasjon. Informasjonsforvaltning.

Kunnskapsdepartementet. (2015a). Fremtidens skole. Fornyelse av fag og kompetanser. NOU 2015:8. Oslo: Departementenes sikkerhets- og serviceorganisasjon. Informasjonsforvaltning.

Kunnskapsdepartementet. (2015b). A høre til - Virkemidler for et trygt psykososialt skolemiljø. NOU 2015:2. Oslo: Departementenes sikkerhets- og serviceorganisasjon Informasjonsforvaltning.

Lie, B. (2014). Eksepsjonelle og dobbelt eksepsjonelle elever: begavede elever og begavede elever med lerevansker. Oslo: Cappelen Damm Akademisk.

Lie, S., Kjærnsli, M., Roe, A. \& Turmo, A. (2001). Godt rustet for framtida? Norske 15-åringers kompetanse $i$ lesing og realfag $i$ et internasjonalt perspektiv. Oslo: Programme for International Student Assessment og Institutt for lærerutdanning og skoleutvikling, Universitetet i Oslo. (Acta Didactica 4/2001).

Liedman, S.-E. (1997). I skuggan av framtiden. Modernitetens historia. Stockholm: Bonnier Alba.

Lindensjö, B. \& Lundgren, U. P. (2000). Utbildningsreformer och politisk styrning. Stockholm: HLS Förlag.

Markussen, E., Frøseth, M. W. \& Sandberg, N. (2011). Reaching for the Unreachable: Identifying Factors Predicting Early School Leaving and Non-Completion in Norwegian Upper Secondary Education. Scandinavian fournal of Educational Research, 55(3), 225-253.

Mathiesen, I. H. \& Vedøy, G. (2012). Spesialundervisning - drivere og dilemma (Vol. 2012/017). Stavanger: IRIS, International Research Institute of Stavanger.

Nordahl, T. \& Hausstätter, R. S. (2009). Spesialundervisningens forutsetninger, innsatser og resultater. Hamar: Høgskolen i Hedmark.

Nordahl, T. Mausethagen, S. \& Kostøl, A. (2009). Skoler med liten og stor forekomst av atferdsproblemer. Elverum: Høgskolen i Hedmark, rapport nr. 3-2009.

Nordahl, T. \& Sunnevåg, A. K. (2008). Spesialundervisningen i grunnskolen: stor avstand mellom idealer og realiteter. Elverum. Høgskolen i Hedmark: Rapport nr. 2.

OECD. (1999). Inclusive Education at Work. Paris: OECD Publishing.

OECD. (2011). Reviews of National Policies for Education: Improving Lower Secondary Schools in Norway 2011. Paris. OECD Publishing.

OECD. (2015). Education Policy Outlook 2015: Making Reforms Happen. Paris: OECD Publishing.

Payne, C. M. (2010). So Much Reform, So Little Change. Cambrigde: Harvard Education Press.

Persson, B. \& Persson, E. (2012). Inkludering och måluppfyllelse: att nå framgång med alla elever. Stockholm: Liber.

Røvik, K. A. (2014a). Reformideer og deres tornefulle vei inn i skolefeltet. I K. A. Røvik, T. V. Eilertsen \& E. M. Furu (Red.), Reformideer $i$ norsk skole. Spredning, oversettelse og implementering (s. 13-50). Oslo: Cappelen Damm Akademisk.

Røvik, K. A. (2014b). Translasjon - en alternativ doktrine for implementering. I K. A. Røvik, T. V. Eilertsen \& E. M. Furu (Red.), Reformideer $i$ norsk skole (s. 403-417). Oslo: Cappelen Damm Akademisk.

Røvik, K. A. \& Pettersen, H. M. (2014). Masterideer. I K. A. Røvik, T. V. Eilertsen \& E. M. Furu (Red.), Reformideen $i$ norsk skole. Spredning, oversettelse og implementering. (s. 53-86). Oslo: Cappelen Damm Akademisk.

Sarason, S. B. (1990). The Predictable Failure of Educational Reform. San Francisco: Jossey-Bass Publishers.

Simonsen, E. (2012). «Folkeskolens ytterste forpost» - en annen historie om den norske folkeskolen 1945-1970. I S. Wiborg, B. R. Larsen, J. E. Larsen, L. R. Rasmussen \& C. Larsen (Red.), Årbog for uddannelseshistorie 2012. (s. 118-144). København: Selskabet for skole- og uddannelseshistorie.

Skrtic, T. (1992). The Special Education Paradox. I T. Hehir \& T. Latus (ed.), Special Education at the Century's End. Evolution of Theory and Practice Since 1970. (s. 203-272). Reprint Series No. 23.: Harvard Educational Review.

Slavin, R. E., Karweit, N. L. \& Madden, N. A. (1989). Effective programs for students at risk. Boston: Allyn and Bacon.

Stangvik, G. (1987). Livskvalitet for funksjonshemmede: 1: Normaliseringsprinsippet som grunnlag for forbedring av livskvalitet. Oslo: Universitetsforlaget.

Statistisk sentralbyrå. (2015). Gjennomstrømning $i$ videregående opplcering, 2009-2014. Henta 06.04. 2016, frå https:/www.ssb.no/utdanning/statistikker/vgogjen/aar/2015-06-04 
Statsministerens kontor. (2012). Rapport fra 22. juli-kommisjonen. NOU 2012:14. Oslo: Departementenes servicesenter. Informsjonsforvaltning.

Telhaug, A. O. (1990). Den nye utdanningspolitiske retorikken. Oslo: Universitetsforlaget.

UNESCO. (1994). The Salamanca Statement and Framework for Action on Special Needs Education. World Conference on Special Needs Education: Access and Quality. Salamanca Spain 7-10 Fune 1994. Paris: UNESCO.

Utdanningsdirektoratet. (2012). Statistikkrapport. Barn, unge og voksne med innvandrerbakgrunn $i$ grunnopplaringen. Oslo: Utdanningsdirektoratet.

Utdanningsdirektoratet. (2014). Utdanningsspeilet 2014. Henta 06.04. 2016, frå http://utdanningsspeilet.udir. no/2014/

Vislie, L. (2003). From integration to Inclusion: focusing global trends and changes in the western European societies. European Fournal of Special Needs Education, 18(1), 17-35.

von Oettingen, A. (2001). Det pedagogiske paradoks - et grundstudie i almen padagogikk. Århus: Klim.

Wendelborg, C. (2016). Mobbing, krenkelser og arbeidsro i skolen Analyse av Elevundersøkelsen skoleåret 2015/16. Trondheim: NTNU Samfunnsforskning, Rapport 2016. 